\title{
Syn-Collision Folding and Multi-Layers Detachment in the Molassic Basin, Northeastern Tunisia
}

\author{
A. Ramzi ${ }^{a, *}$, M. Noureddine ${ }^{b}$, and C. Lassaad ${ }^{b}$ \\ ${ }^{a}$ Department of Earth Sciences, Faculty of Sciences of Gafsa, University of Gafsa, Gafsa, Sidi Ahmed Zarrouk, 2112 Tunisia \\ ${ }^{b}$ Department of Earth Sciences, Faculty of Sciences of Bizerte, University of Carthage, Jarzouna-Bizerte, 7021 Tunisia \\ *e-mail: razizi61@yahoo.fr \\ Received October 10, 2019; revised July 11, 2020; accepted July 28, 2020
}

\begin{abstract}
Tunisia had been the place of various tectonic episodes which have drawn the actual structural map of the country. The Neogene period was the most active period in which the collision contributed to the mountain ranges formation such as the Atlassic chain. The contrast of mechanical behavior between the different sedimentary units of the cover and the substratum is a determining factor that has controlled the deformation style of many folding structures. Detachment folding has been studied on the basis of field and seismic data examples from the Northeastern Tunisia. We discuss different aspects of detachment to constrain the chronology of structural events and understand the cover-substratum relationship during the major folding phases. In the present paper, we found that the deformation style admitted previously do not reflect adequately the tectonic structure of Kechabta Neogene basin (North of Tunisia). The cover-substratum relationship study at this area revealed two major shortening phases; the first had been happened during the Upper Tortonian and the second in the Lower Quaternary. The resulting folding style is characterized by disharmonic and multi-layers detachment phenomena produced by incompetent evaporitic sequences. The two described folding phases are superimposed and testify at a large scale the continental collision which controls the North African margin during the Late Miocene to the Quaternary.
\end{abstract}

Keywords: syn-collision, folding, detachment, cover-substratum system, multi-layers, Tunisia

DOI: $10.1134 / \mathrm{S} 0016852120060102$

\section{INTRODUCTION}

The relationship between cover-substratum (basement) has long been the focus of many researchers [10, $12,16,28,31,34,37,38]$ due to its importance in understanding the tectonic deformation style, especially detachment phenomenon. The variations in structural styles of detachment folds are related to magnitude of shortening, asymmetry, faulting, and the occurrence of multiple detachments [38, 47]. However the identification of the cover-basement relationship becomes much more difficult in terranes that witnessed superimposed folding. Over all, according to Jamison [27] and Dahlstrom [11], the detachment folds correspond to disharmonic folds and usually develop in series of sedimentary beds characterized by high lithological contrast and thick incompetent layers. In addition, the incompetent layers correspond to the detachment intervals on top of which the competent layers are deformed [16, 26, 42]. However, the wavelength and the amplitude of the folds formed vary according to the contrast of the series characteristics such as the competence and the thickness [44]. The fold geometry and evolution are strongly dependent on the mechanical stratigraphy, including the thick- ness, ductility, and stratigraphic sequence of the units $[12,38]$.

At the Atlassic area of North African margin, the detachment is described in the Triassic evaporitic series $[4,19,33]$. The sedimentary cover detachment was revealed to be contemporary with the different stages of the African-Eurasian convergence that led to the Alpine chain and the Atlassic chain formation [3, $15,40]$ during the Mesozoic-Cenozoic age. In the Northeastern part of Tunisia (Kechabta Neogene basin), the Neogene series are characterized by a set of evaporate formations series that show the same lithological and mechanical characteristics of the Triassic especially the incompetent series (sands, clays and gypsum). This similarity allows us to think of another structural interpretation with the existence of detachment phenomenon differently to simple folding described in previous works $[24,35]$. The objective of this study is the analysis of the cover-basement relationship during the folding phases and the explanation of some tectono-sedimentary manifestations such as sedimentary gaps. We also tried to integrate the documented evolutionary history of Kechabta basin in the collision context which affected the North African margin during the Neogene. 


\section{GEOLOGICAL SETTING}

Tunisia constitutes the eastern extension of the Maghrebides chain of North Africa which is a part of the peri-Mediterranean Alpine chain [15, 17]. Kechabta Neogene basin is located in the northeast of Tunisia (Fig. 1). It is a subsiding molassic basin, which develops during the Mio-Plio-Quaternary at the front of thrust sheets of the Alpine Tunisian chain [3,5]. The study area of Kechabta basin is limited on the northwest by the thrust sheets area represented by the Numidian flysch which was moved from NW to SE during the Early Oligocene to the Middle Miocene [45]. On the southwest, the Kechabta basin is limited by imbricated area formed by the Paleocene marl, Nummulitic limestone of the lower Eocene and a clays and sandstones of the Miocene [30]. On the South, the study area is limited by the diapir zone [40] marked by the Triassic outcrops.

The Kechabta Neogene basin shows a series dominated by the Neogene outcrops with a few outcrops of Mesozoic and Paleogene deposits. The ante-Neogene series rarely exposed in the Kechabta basin are located near to the major faults such as the NE-SW fault of El Alia (Figs. 1b, 2). The Triassic series consists of a breccia facies composed of gypsum, clay, limestones, dolomites, sandstones and siltstones. It is a significant geological level characterized by disharmony phenomenon in the structural evolution of whole Tunisia [6, 33].

In the Kechabta basin, we found:

(1) the limestones of the Abiod formation (Campanian-Maastrichtian), clays and marls of El Haria formation (Paleocene), two facies of yellowish limestones;

(2) Bou Dabbous formation with Globigerina and El Garia formation with Nummulites of the Ypresian age [7] and a Glauconitic marls, clays and sandstones of the Fortuna formation (Oligocene).

The Neogene-Quaternary sequence constitutes a thick $(>3000 \mathrm{~m})$ succession of sedimentary rocks that has classically been divided into:

(1) Hkima formation (Langhian-Serravallian): it consists of a 500 to $570 \mathrm{~m}$ thick lagoonal series rich with gypsum intercalations and made up of variable clays, silty sandstones and red or black marls [7, 23]. This succession begins with polymictic conglomerates.

(2) Oued El Meleh formation (Serravallian-Lower Tortonian): it consists of a $300 \mathrm{~m}$ thick evaporitic sequence made up of grey-greenish marls, passing upwards to lens-shaped to massive gypsum beds and some alternations of clays and sandstones [19, 29].

(3) Kechabta formation (Middle Tortonian): consists in an open marine thick (1500 to $2000 \mathrm{~m}$ ) series made up of alternations of flysch (clays and sandstones). This formation contains traces of pyrite and fossil fragments. It was deposited in a shallow, but quickly subsiding marine environment [7, 23].
(4) Oued Bel Khedim formation (Messinian): represented by a margin-littoral to lacustrine series made up of alternations of clays, gypsum (evaporitic basal unit, $200 \mathrm{~m}$ thick) and lacustrine limestone (lacustrine top Unit, $80 \mathrm{~m}$ thick) [8, 21].

(5) Chaabat Et Tabbala formation (Pontian): represents a continental succession composed of red siltstones, fine conglomerates [8, 29] with thickness varying between 50 to $100 \mathrm{~m}$. Both Oued Bel Khedim and Chaabat Et Tabbala formations represent two episodes of what is commonly known as the Messinian Salinity Crisis around the Mediterranean peripheral basins [24].

(6) The Pliocene transgressive series of Raf Raf (200 $\mathrm{m}$ thick) and Porto Farina (260 m thick) are composed of green clays and yellow sandstones with coquinas and oyster [7].

(7) The Early Pleistocene (Villafranchian): essentially continental facies represented by polymictic conglomerates, red clays and reddish to yellowish silts (Fig. 3).

\section{FOLDING PHASES \\ Upper Tortonian Folding}

As summarized by several authors, events of widespread deformation in the foreland basin of the thrust sheets are thought to have occurred during the Middle Miocene to present-day times. The Upper Tortonian folding phase which is known as the "Atlassic folding," corresponds to the largest folding across Tunisia [2, 3, $32,33]$. The new field observations show that the evaporitic series of Oued Bel Khedim formation (Messinian) are deposited, with angular unconformity, on the open marine thick series of Kechabta formation (Middle Tortonian) [3] (Fig. 4).

The secondary and tertiary cover deposits are ubiquitous in the Tunisian territories in general and especially in the Kechabta basin. This cover is characterized by the lithological couple type sediments, i.e., sandstone-clay and limestone-marl which have different competency and, therefore, different mechanical behaviors against the exerted tectonic stresses.

During the Upper Tortonian, NW-SE-directed compression affected the incompetent miocene series of Hkima, Oued El Meleh, and Kechabta formations. This series were deposited on a competent and resistant substratum formed by the Ypresian limestone (Fig. 3), thus, the difference in the mechanical properties between the Neogene cover and its substratum caused the detachment phenomenon. Consequently, the deformation style ensured by detachment gives birth to disharmonic folds. The cover represented by all formations of Hkima, Oued El Meleh, and Kechabta, was independently deformed from their substratum which formed by the resistant Ypresian limestone. During the Upper Tortonian folding, the detachment level is represented by the incompetent series of Hkima and Oued El meleh formations (clays and gypsum). This level forms a kind of a bulge (swelling) at 




Fig. 1. Structural setting of the study area. (a) - Tunisia in the Mediterranean context (after [17], modified); (b) - Structural areas of Northern Tunisia; (c) - Structural sketch of the Kechabta Neogene basin (after [3], modified). 


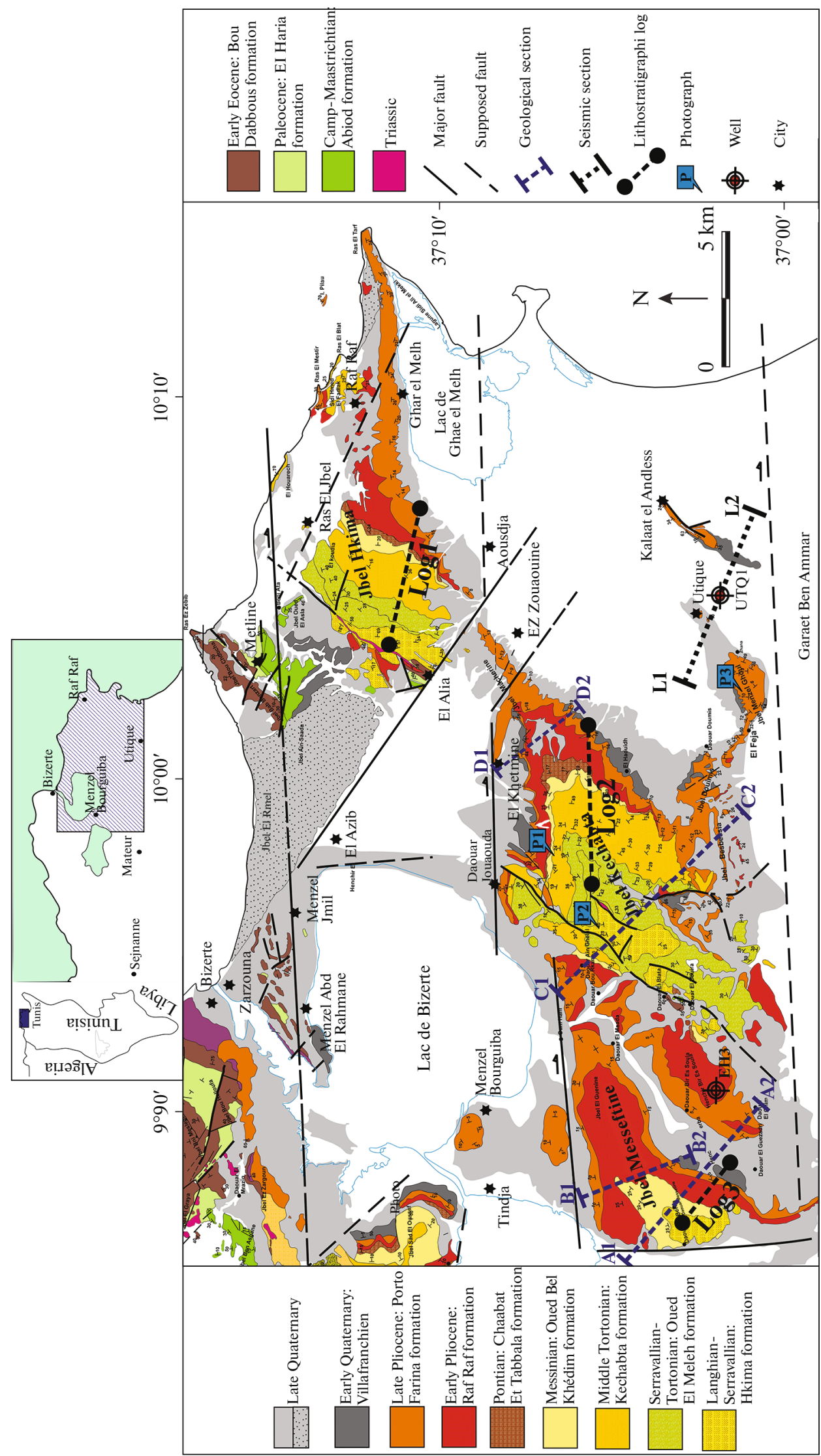

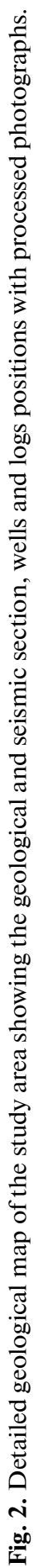






Fig. 3. Generalized stratigraphic column indicating the main detachment horizons and the mechanical series properties in the Kechabta basin.

the cores of anticlines by migration of incompetent materials upwards (Figs. 5, 6).

The detachment of the Neogene cover from its substratum at the Miocene evaporites level appears very clearly in seismic section (Fig. 6) and the photographs
(Fig. 7) showing the migration of the evaporitic materials to the top. The presence of disharmonic folds with various axis direction and high plunges, the elemental detachment affecting the sandstone-clays alternation and the second- order folds form a kind of shock 


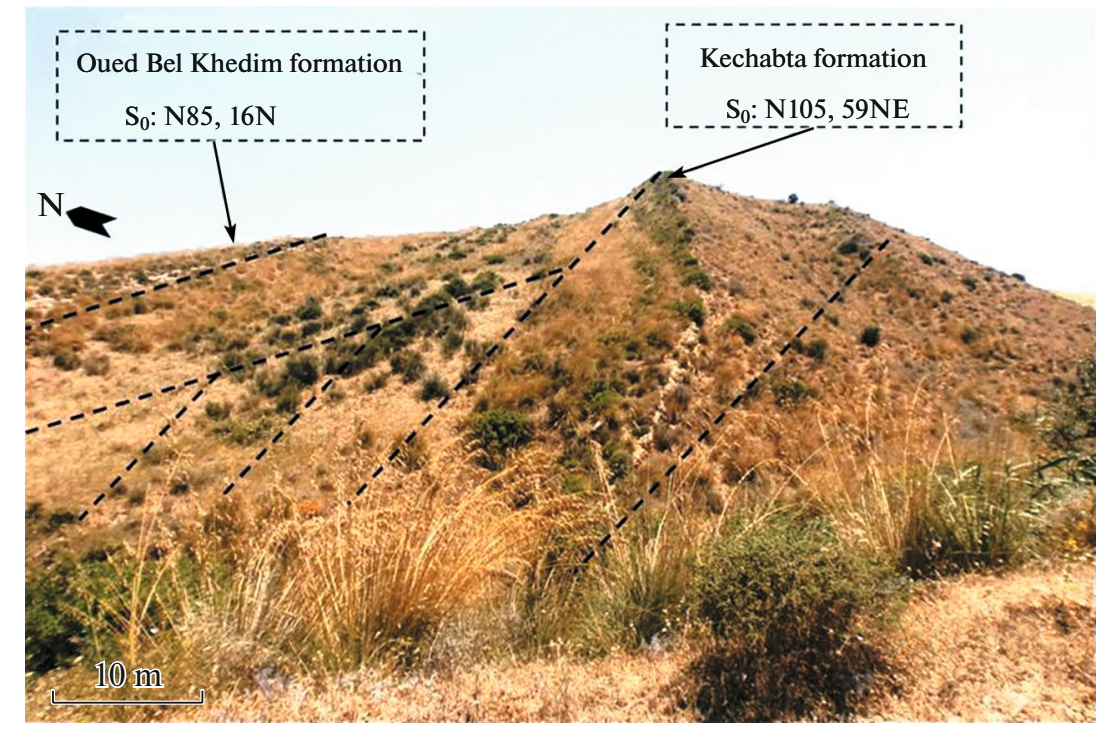

Fig. 4. Interpreted photograph (see P1 in Fig. 2) showing the angular unconformity between Oued Bel Khedim formation (Messinian) and Kechabta formation (Middle Tortonian).
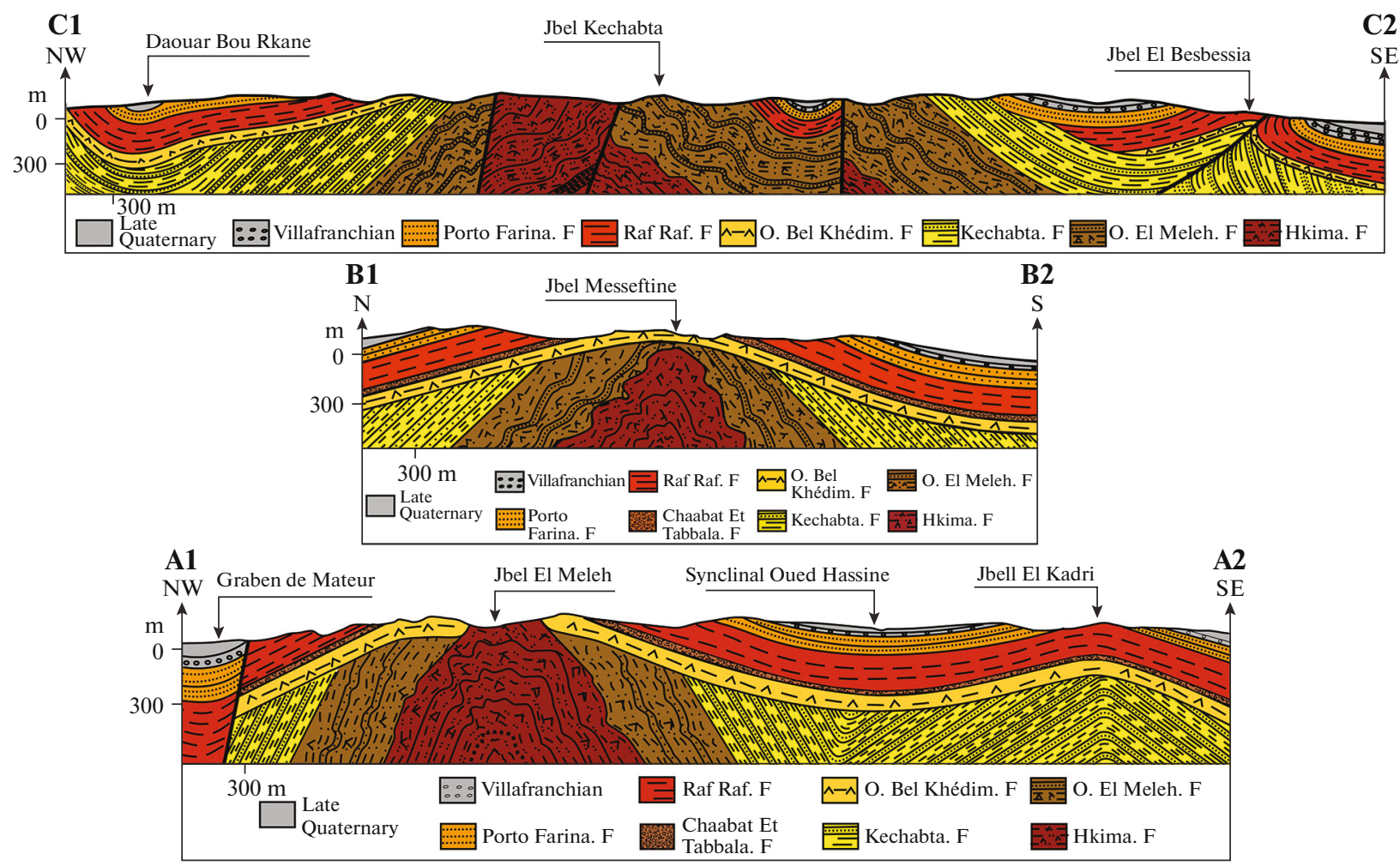

Fig. 5. Geological sections $\mathrm{A} 1-\mathrm{A} 2, \mathrm{~B} 1-\mathrm{B} 2$, and $\mathrm{C} 1-\mathrm{C} 2$ showing the tectonic deformation, the angular unconformities and the mechanical properties of geological materials at Kechabta basin.

absorbers that absorb and slow the compressive deformation without forming faults (Fig. 7). The Upper Tortonian folding is responsible for the formation of NE-SW-trending folds such as the anticlines of Jbel Messeftine, Jbel Kechabta, and Jbel Hkima.

\section{Lithostratigraphic Observation}

The lithostratigraphic correlation (Fig. 8) shows a lateral variation of the Neogene deposits thickness in Kechabta basin. This variation is registered mainly by the thicknesses of Oued El Meleh and Kechabta for- 


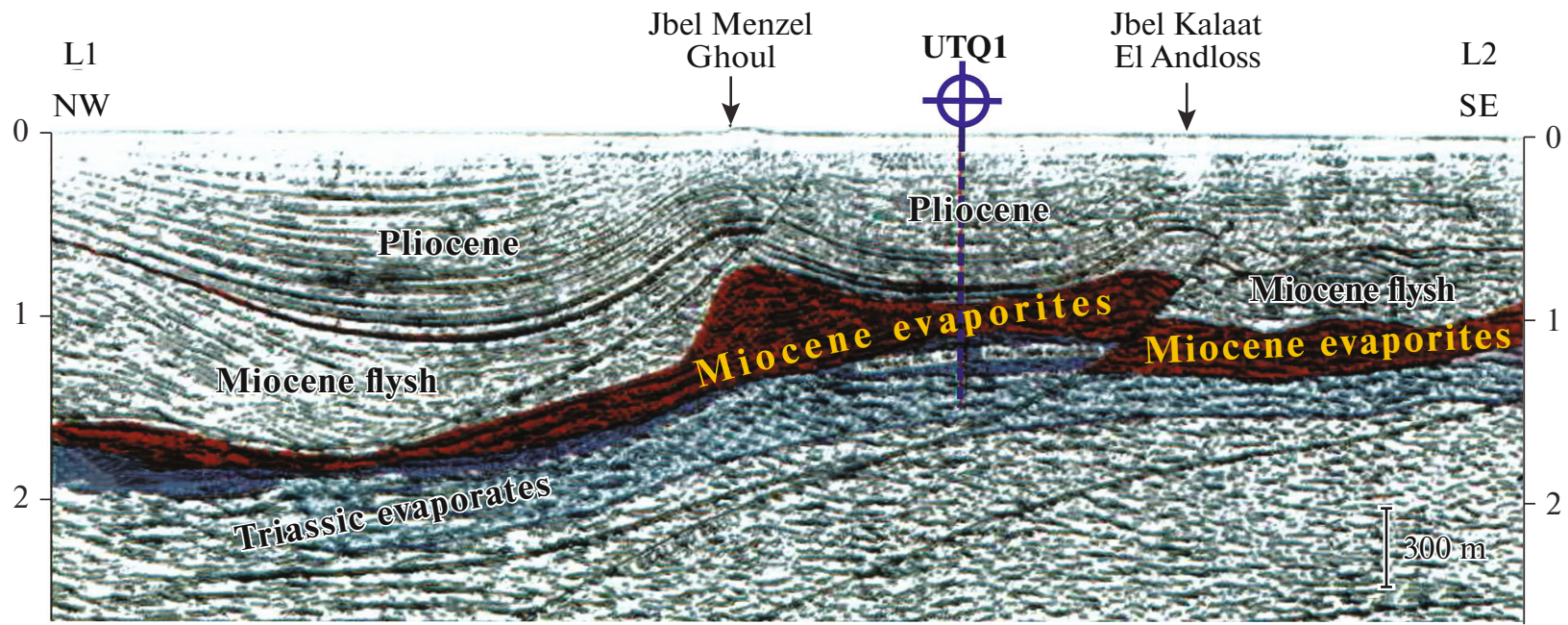

Fig. 6. Interpreted seismic profile L1-L2 showing the detachment phenomenon controlling the development of anticline structures in the study area.

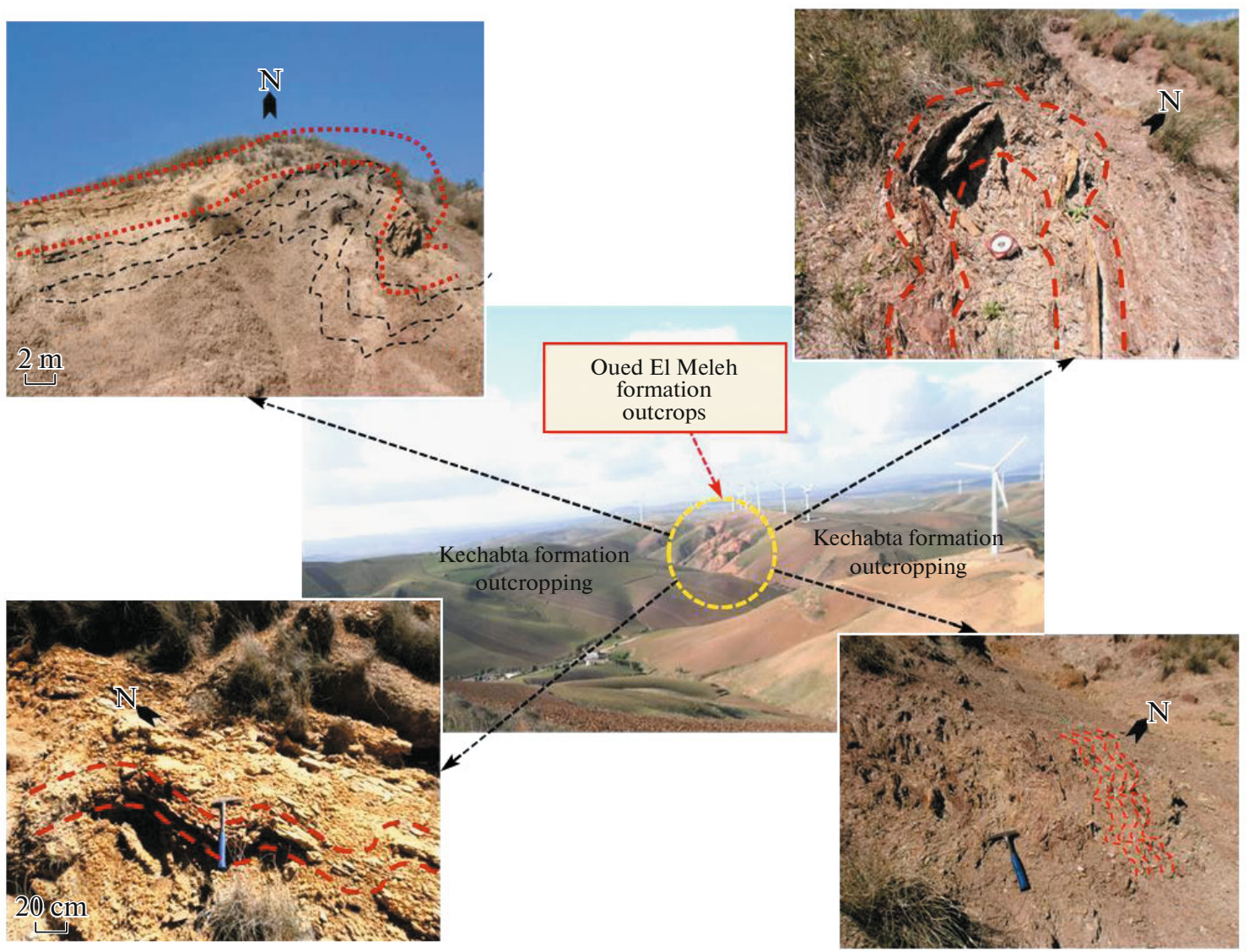

Fig. 7. Photographs (see P2 in Fig. 2) showing a vertical axis of disharmonic folds with elementary detachment at different scales affecting the sandy and clay intercalations of Oued El Meleh formation (Langhian-Serravallian). 


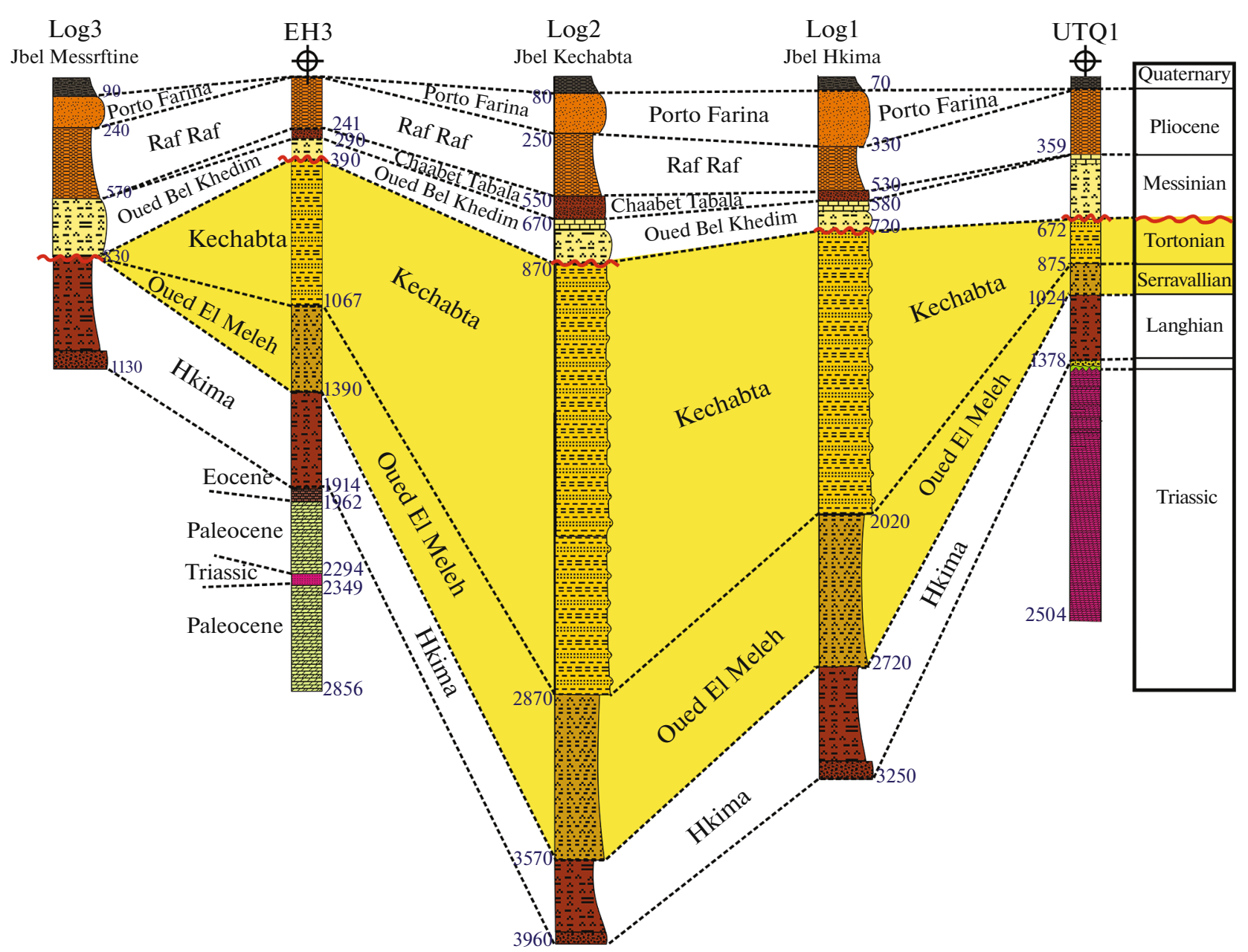

Fig. 8. Lithostratigraphic correlation of the Neogene series at the Kechabta basin showing the sedimentary gap of Oued El Meleh and Kechabta formations at Jbel Messeftine.

mations (Serravallian-MiddleTortonian) ranging from $400 \mathrm{~m}$ at the Utique well (UTQ1), $2000 \mathrm{~m}$ at Jebel Hkima (Log1), $2700 \mathrm{~m}$ at Jebel Kechabta ( $\log 2)$, $1000 \mathrm{~m}$ at E1 Haroune well (EH3) and a total absence in Jebel Messeftine (Log3). At Jbel Messeftine, the evaporitic deposits of Oued Bel Khedim Formation are deposed directly on the Hkima Formation. The local sedimentary gap of Oued El Meleh and Kechabta formations was highlighted in the previous works [7, $14,19,23,24]$ where it was explained by the existence of an erosion area during the Serravallian-Middle Tortonian. The main drawback of this hypothesis is that didn't take into account the original character of the sedimentary series, especially the incompetent nature of the Miocene formations.

\section{Lower Quaternary Folding}

This shortening phase is known as the post-Villafranchian phase $[3,7,19,35,36,46]$. This compression phase gave rise to NE-SW- and E-W-trending folds in Jbel Kechabta, Jbel Messeftine, and El Alia area. In addition, the post-Villafranchian folding was responsible for new reverse faults formation (Figs. 9, 10) and the reactivation of the preexisting faults. Throughout the post-Villafranchian folding, probably a new detachment was happened at the Messinian-Pliocene evaporite layers.

\section{RESULTS AND DISCUSSION}

In the North of Tunisia, the Maghrebides chain formation occurred during the Oligocene-Middle Miocene interval, concomitant with the destruction of the old Alboran plate [1, 13, 20, 39, 48]. This destruction was engineered by a regional NW-SE compressive regime imposed by the continental subduction leading to the establishment of thrust sheets and molassic basins (Fig. 1b).

\section{During the Upper Tortonian: Supple Cover and Rigid Substratum (Thin-skinned Fold)}

During the Upper Tortonian, a compressive regime affects the North of Tunisia and Algeria, this folding 




Fig. 9. Geological section D1-D2 showing the second detachment level recorded in Raf Raf formation (Early Pliocene).

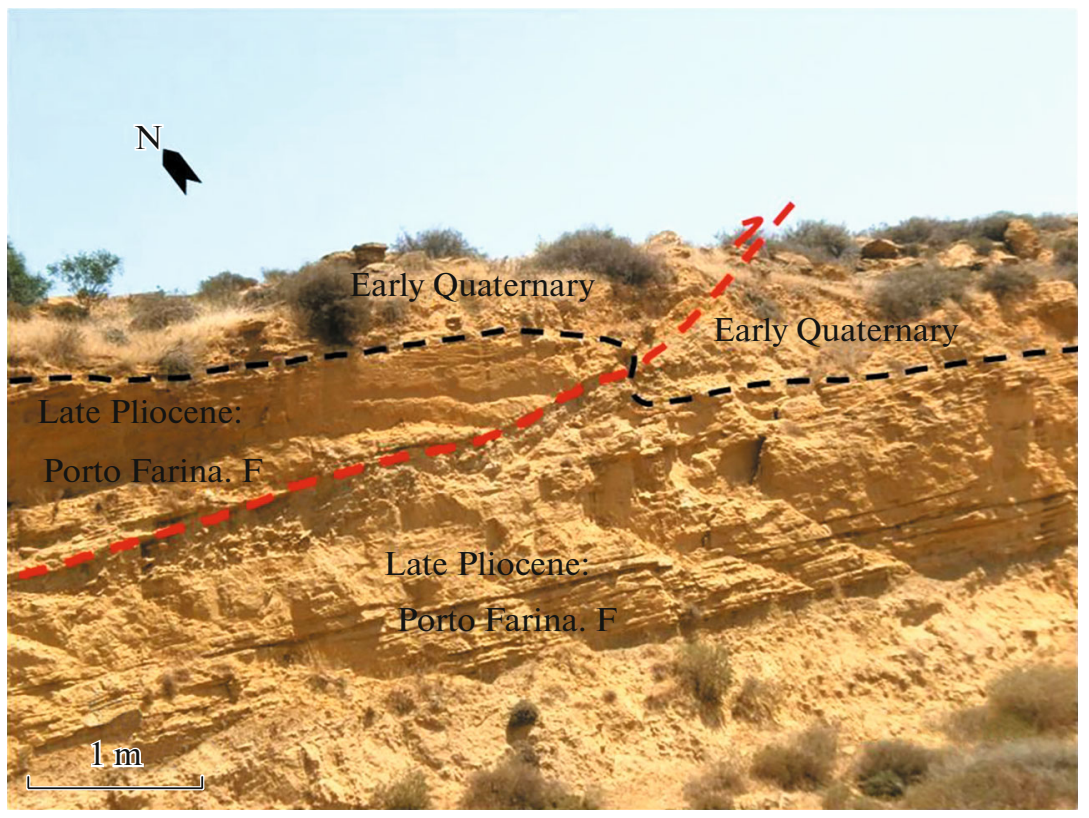

Fig. 10. Interpreted photograph (see P3 in Fig. 2) showing of a reverse fault affecting the Late Pliocene and the Early Quaternary deposits at Jbel Menzel Ghoul-Utique.

episode is related to the obstruction of the continental subduction in North Africa and its transition into the collision [9, 18, 41, 48]. At Kechabta Neogene basin, the Upper Tortonian folding is proved by an angular unconformity separating the evaporite series of Oued Bel Khedim from the underlying flysch of Kechabta formation. It is the Atlassic folding phase which has shaped the landscape of the Tunisian foreland basin before giving birth to NE-SW folds perpendicular to the NW-SE axis of the regional shortening direction $[2,3,32,33]$. In the Northeastern Tunisia, this folding event affects the Neogene incompetent materials and forms a NE-SW folds axis direction in Jbel Messeftine, Jbel Kechabta, and Jbel Hkima. These folds are characterized by large wavelengths (kilometric order) and relatively low amplitudes caused by the presence of thick evaporites of the Miocene series (these series exceeds $3000 \mathrm{~m}$ ). In addition, these folds are still characterized by asymmetric geometry of the two limbs with a structure slightly overturned to the SE. A huge contrast of the intrinsic mechanical properties was revealed between the incompetent, frangible, and young series of the Neogene cover and the Eocene substratum with rigid, competent and old series. This contrast caused the detachment of the cover from its substratum. At Kechabta Neogene basin the detachment layers during the Upper Tortonian folding are the clays, sandstones and gypsum marls of Hkima and Oued El Meleh formations (Fig. 11). During this compressive phase, both incompetent formations acted as a detachment level in which the material fled upwards from the Ypresian substratum forming a bulge (pillow) in the cores of folds (Fig. 6). The main structure is compatible with a thin-skinned style deformation.

\section{Tectono-Sedimentary Manifestation}

The Upper Tortonian compressive phase and the folding style with detachment between the cover and the basement helps to explain the local lack of Oued El Meleh and Kechabta formations in the Jebel Messeftine region (Fig. 5, sections $\mathrm{A} 1-\mathrm{A} 2$ and $\mathrm{B} 1-\mathrm{B} 2$, Fig. 8). In this area, the detachment level of Hakim and Oued El Meleh formations formed a kind of bulge evaporites dome that pierced the cover (Kechabta formation) and reached the surface following the erosive 


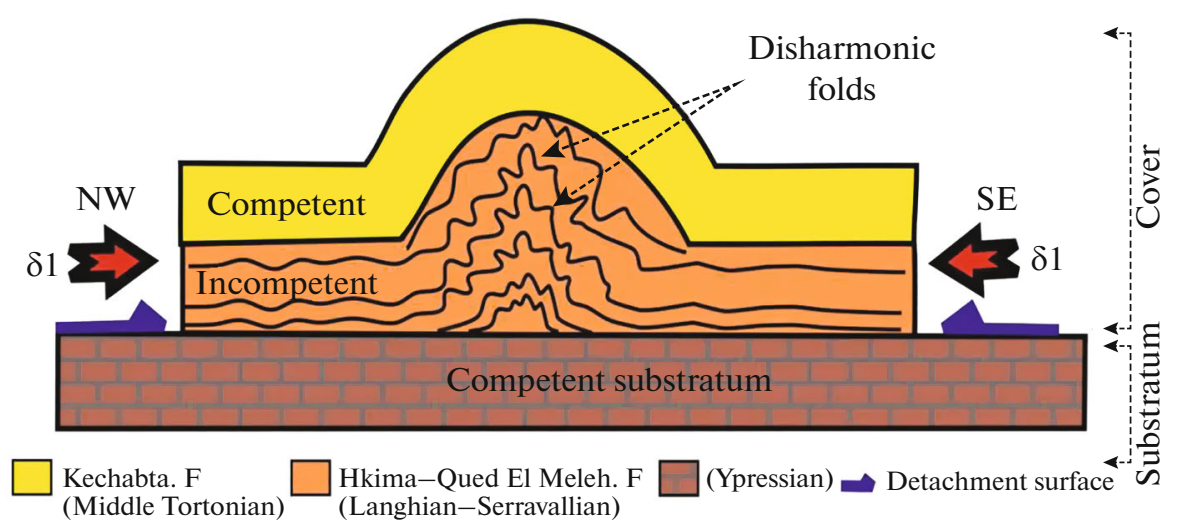

Fig. 11. 2D model explaining the style of deformation in thin-skinned fold structure at the Northeastern of Tunisia during the Upper Tortonian shortening.

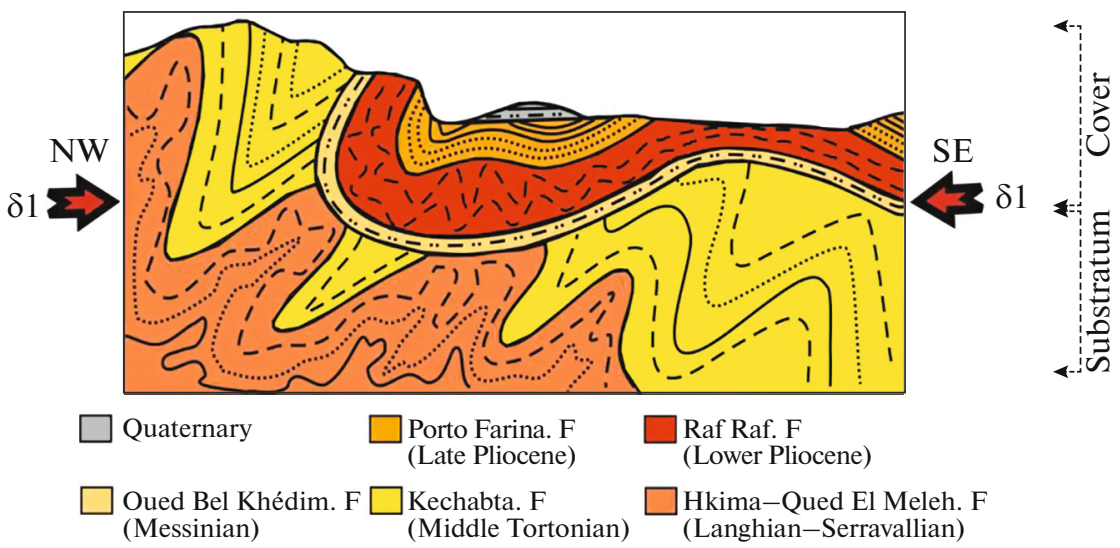

Fig. 12. 2D model explaining the tectonic structure with multi-layers detachment at the Northeastern of Tunisia during the Late Quaternary folding.

phase after the folding episode. Thereafter, at the Messinian, the Oued Bel Khedim formation comes to deposit directly with angular unconformity on Hkima formation (Langhian) (Fig. 5, sections A1-A2 and B1-B2). In the Jebel Messeftine area, Oued El Meleh, and Kechabta series exist at depth but far away from the evaporite dome (anticline core) which is recorded in the well EH3. Located at $7 \mathrm{~km}$ near the Jebel Messeftine, this well presents $1000 \mathrm{~m}$ of thickness of these two geological formations. This local cartographic gap, caused by the detachment phenomenon (evaporite dome), recalls the Triassic evaporite structures in Tunisian foreland basin (domes area) where the incomplete sedimentary series are observed only in the surface outcrops $[22,25,40]$.

\section{During the Post-Villafranchian: Supple Cover on Supple Substratum Already Deformed (Multi-Layer Detachment)}

During the second folding episode of post-Villafranchian a NW-SE to NNW-SSE compression direction affected the Neogene and the Quaternary series in the geodynamic context of collision [9, 18, 41].
During this shortening phase, the Messinian-villafranchian series played the role of a sedimentary cover deposited on a substratum represented by all series of Langhian-Middle Tortonian already deformed by the anterior Upper Tortonian folding (Fig. 12). For the superposed folding in the Kechabta basin, the second folding phase followed passively the previous shortening with almost the same compression direction (NW-SE to NNW-SSE) and kept the same fold axis.

The final structure follows a complex deformation style, it is the most difficult case where there is more than a detachment level (multi-layer detachment) and there is a superposition of two folding phases. In this case, without forming faults, the Miocene substratum (Hkima, Oued El Meleh, and Kechabta formations) was passively deformed in the same way as its sedimentary cover (Oued Bel Khedim, Chaabet Tabbala, Raf Raf, and Porto Farina formations). This substratum deforms independently to its previous structure. The superimposed folds resulting from the two compression phases in the Kechabta Neogene basin are type " 0 " folds formations (redundant superposition) according to Ramsey's classification in 1967 [3]. 


\section{CONCLUSIONS}

The polyphase neogene compression and the tectonic style for each shortening phase in the Kechabta basin were remained fuzzy and unfocused for a long time because of the scarcity of data and arguments. In this study, we were able to characterize the deformation style of the two major folding phases affecting the incompetent Neogene series, which constitute the biggest challenge for this paper. During the first NW-SE compression of the Upper Tortonian, the tectonic style in the Kechabta basin is characterized by disharmonic detachment folds produced at the evaporitic layers of Hkima and Oued El Meleh formations. The contrast of mechanical behavior between the different sedimentary units of the cover and the substratum controlled largely the deformation style and caused the local gap of some geological formations. During the second folding phase of the post-Villafranchian, the detachment phenomenon continues, but with more complexity of mechanical conditions because both the cover and the substratum are an incompetent series. The final style of deformation is represented by multi-detachment folds which are the result of syncollisional folding with two superimposed and tectonized angular unconformities.

\section{ACKNOWLEDGMENTS}

We thank the Editor-in-Chief and the Editorial Board, as well as reviewer Prof. V.N. Puchkov (the Main Researcher of the Institute of Geology and Geochemistry of the Uralian Branch of Russian Academy of Science, Ekaterinburg, Russia) for the constructive comments and for help in improving the clarity of the paper.

We are also grateful to the Tunisian National Oil Company (ETAP) for the interpreted seismic section.

\section{OPEN ACCESS}

This article is distributed under the terms of the Creative Commons Attribution 4. International license (http://creativecommons.org/licenses/by/4.0/), which permits unrestricted use, distribution, and reproduction in any medium, provided you give appropriate credit to the original author(s) and the source, provide a link to the Creative Commons license, and indicate if changes were made.

\section{ADDITIONAL INFORMATION}

The publication of this Open Access article was funded by Pleiades Publishing.

\section{REFERENCES}

1. D. F. Argus, R. G. Gordon, C. De Mets, and S. Stein, "Closure of the Africa-Eurasia-North America plate motion circuit and tectonics of the Gloria fault," J. Geophys. Res., B 94, 5585-5602 (1989).

2. R. Azizi, A. Kadri, and L. Chihi, "Neogene tectonic evolution in Northern Tunisia: Case of Chaouat-Man- nouba area. Palaeoseismic event associated," Arab. J. Geosci. 8, 8911-8925 (2015).

3. R. Azizi and L. Chihi, "Superposed folding in the Neogene series of the Northeastern Tunisia: Precision of the upper Miocene compression and geodynamic significance,” Int. J. Earth Sci. 106, 1905-1918 (2017).

4. M. Bédir, L. Zitouni, N. Boukadi, J. Saadi, R. Alouani, F. Ben Timzal, S. Tlig, and C. Bobier, "Rifting, halocinèse et structuration des bassins péri-téthysiens jurassique et crétacé inférieur de subsurface du domaine atlasique central de la Tunisie (région de Gafsa-Sidi Ali Ben Aoun)," Afr. Geosci. Rev. 7, 289-306 (2000).

5. N. Ben Ayed, C. Viguier, and C. Bobier, "Les éléments structuraux récents essentiels de la Tunisie nord-orientale," Notes Serv. Geol., Tunis. 47, 5-19 (1983).

6. C. Bobier, C. Viguier, R. Chaari, and A. Chine, "The post-Triassic sedimentary cover of Tunisia: Seismic sequences and structure," Tectonophysics 195, 371- 410 (1991).

7. P. F. Burollet, "Etude géologique des bassins Francepliocènes du Nord-est de la Tunisie (région entre Mateur, Ferryville et Porto-Farina), ” Notes Serv. Geol., Tunis. 7, 86 (1951).

8. P. F. Burollet and H. Rouvier, "La Tunisie," in Tectonique de l'Afrique (UNESCO, Paris, 1971), pp. 91-100.

9. L. Chihi and H. Philip, "Le bloc Atlaso-pélagien: place et évolution géodynamique dans le contexte subduction-collision de la Méditerranée centrale (Afrique du nord-Sicile) du Miocène au Quaternaire,” Notes Serv. Geol., Tunis. 65, 49-68 (1999).

10. B. Christian, S. Carolin, C. T. David, and W. Jutta, "Paleostress pattern and salt tectonics within the developing foreland basin (north-western Subhercynian basin, Northern Germany), ' Int. J. Earth Sci. 102, 22392254 (2013).

11. C. D. A. Dahlstrom, "Geometric constraints derived from the law of conservation of volume and applied to evolutionary models for detachment folding," AAPG Bull. 74, 336-344 (1990).

12. D. M. Davis and T. Engelder, "The role of salt in foldand-thrust belts," Tectonophysics 119, 67-88 (1985).

13. J. Dercourt, L. P. Zonenshain, L. E. Ricou, V. G. Kazmin, X. Le Pichon, A. L. Knipper, C. Grandjacquet, I. M. Sbortshikov, J. Geyssant, C. Lepvrier, D. H. Pechersky, J. Boulin, J. C. Sibuet, L. A. Savostin, O. Sorokhtin, et al., "Geological evolution of the Tethys belt from the Atlantic to the Pamirs since the Lias," Tectonophysics 123, 241-315 (1986).

14. M. Dlala, J. Kacem, F. Ben Mehrez, H. Philip, and L. Mejri, "Tectonique récente, sismotectonique et Alea sismique régional de la région de Kechabta-Messeftine et des environs (Tunisie Nord orientale)," Notes Serv. Geol., Tunis. 75, 13-34 (2007).

15. M. Durand-Delga, "La Méditerranée occidentale: étapes de sa genèse et problèmes structuraux liés à celleci,” Mem. Hors-Ser. Soc. Geol. Fr. 10, 203-224 (1980).

16. J. L. Epard and R. H. J. Groshong, "Kinematic model of detachment folding including limb rotation, fixed hinges and layered-parallel strain," Tectonophysics 247, 85-103(1995).

17. C. Faccenna, T. W. Becker, P. F. Lucente, L. Jolivet, and F. Rossetti, "History of subduction and back-arc extension in the Central Mediterranean," Int. J. Geophys. 145, 809-820 (2001). 
18. D. Frizon de Lamotte, B. S. Bezar, R. Bracène, and E. Mercier, "The two main steps of the Atlas building and geodynamics of the western Mediterranean," Tectonics 19, 740-761 (2000).

19. H. Gabtni, C. Jallouli, K. L. Mickus, M. M. Turki, M. Jaffal, and P. Keating, "Basement structure of southern Tunisia as determined from the analysis of gravity data,” Implic. Pet. Explor. Geosci. 18, 143-152 (2012).

20. E. Garcia, J. Dañobeitia, J. Verges, R. Bartolome, and D. Cordoba, "Crustal architecture and tectonic evolution of the Gulf of Cadiz (SW Iberian margin) at the convergence of the Eurasian and African plates," Tectonics 22, 1033-1058 (2003).

21. D. L. Griffin, "Aridity and humidity: Two aspects of the Late Miocene climate of North Africa and the Mediterranean," Palaeogeogr., Palaeoclimatol. Palaeoecol. 182, 65-91(2002).

22. M. Hammami, A. Braham, N. Hatira, and N. Ben Ayed, "Synchronisme "tectonique-halocinese" dans la partie médiane de la zone des diapirs (Tunisie septentrionale)," Notes Serv. Geol., Tunis. 67, 67-86 (2001).

23. S. Harrab, M. Rabhi, B. Mannai-Tayech, and F. Zargouni, "Le Messinien en Tunisie septentrionale : contexte géodynamique et impact de la crise de salinité messinienne," Notes Serv. Geol., Tunis. 78, 109-120 (2010).

24. S. Harrab, B. Mannai-Tayech, B. Rabhi, and F. Zargouni, "Study of a Neogene basin dynamics: The "Bizerte basin", northeastern Tunisia: Relevance to the global Messinian Salinity Crisis,” C. R. Geosci. 345, 251-261 (2013).

25. N. Hatira, A. Samati, A. Mansouri, V. Perthuisot, and H. Rouvier, "Le Trias àcaractère extrusif de la zone des dômes: exemple de la structure de Débadib-Ben Gasseur (Tunisie septentrionale)," AAPG Bull. 171, 319326 (2000).

26. T. X. Homza and W. K. Wallace, "Geometric and kinematic models for detachment folds with fixed and variable detachment depths," J. Struct. Geol. 17, 575-588 (1995).

27. J. R. Jamison, "Geometric analysis of fold development in overturned terranes," J. Struct. Geol. 9, 207219 (1987).

28. B. Jonas, R. J. Boris, P. Kaus, and B. Jean-Pierre, "Numerical investigation of deformation mechanics in foldand-thrust belts: Influence of rheology of single and multiple décollements," Tectonics 31 (2012). https://doi.org/10.1029/2011TC003047

29. W. Krijgsman, F. J. Hilgen, I. Raffi, F. J. Sierro, and D. S. Wilson, "Chronology, causes and progression of the Messinian salinity crisis," Nature 400, 652-655 (1999).

30. J. Kujawski, "Résultats de nouvelles observations à l'Est des Hédil (Tunisie septentrionale)," Bull. Soc. Geol. Fr. 9, 735-740 (1967).

31. H. Laubscher, "Balanced sections and the propagation of decollement: A Jura perspective," Tectonics 22 (2003). https://doi.org/10.1029/2002TC001427

32. N. Mahmoudi, F. Ferhi, Y. Houla, R. Azizi, and L. Chihi, "New insights on the tectonic evolution of the Miocene gap grabens of Sers-Siliana (Tunisian Atlas) during Neogene to Quaternary: Contribution of chronology of the regional tectonic events," J. Earth Syst. Sci. 128 (2019).

https://doi.org/10.1007/s12040-019-1220-8

33. A. Masrouhi, M. Gharbi, O. Bellier, and M. Ben Youssef, "The Southern Atlas Front in Tunisia and its foreland basin: Structural style and regional-scale deformation," Tectonophysics 764, 1-24 (2019).

34. S. Marc, M. Jon, and S. Guido, "Multiple detachments during thin-skinned deformation of the Swiss Central Jura: A kinematic model across the Chasseral," Swiss J. Geosci. 108, 327-343 (2015).

35. L. Mejri, V. Regard, S. Carretier, S. Brusset, and M. Dlala, "Evidence of Quaternary active folding near Utique (Northeast Tunisia) from tectonic observations and a seismic profile," C. R. Geosci. 342, 864-872 (2010).

36. F. Melki, T. Zouaghi, S. Harrab, A. Casas Sainz, M. Bédir, and F. Zargouni, "Structuring and evolution of Neogene transcurrent basins in the Tellian foreland domain, north-eastern Tunisia," J. Geodyn. 52, 57-69 (2011).

37. S. Mitra, "Structural models of faulted detachment folds," AAPG Bull. 86, 1673-1694 (2002).

38. S. Mitra, "A unified kinematic model for the evolution of detachment fold," J. Struct. Geol. 25, 1659-1673 (2003).

39. J. M. Nocquet and E. Calais, "Geodetic measurements of crustal deformation in the Western Mediterranean and Europe,” Pure Appl. Geophys. 161, 661-681 (2004).

40. V. Perthuisot, "Diapirism in Northern Tunisia," J. Struct. Geol. 3, 231-235 (1981).

41. A. Piqué, P. Tricart, R. Guiraud, E. Laville, S. Bouaziz, M. Amrhar, and R. Ait Ouali, "The Mesozoic-Cenozoic Atlas belt (North Africa)," Geodin. Acta 15, 185208 (2002).

42. J. Poblet and K. McClay, "Geometry and kinematics of single-layer detachment folds," AAPG Bull. 80, 10851109 (1996).

43. J. G. Ramsay, Folding and Fracturing of Rocks (McGraw-Hill, New York, 1967).

44. J. G. Ramsay and M. I. Huber, The Techniques of Modern Structural Geology, Vol. 2: Folds and Fractures (Academic, London, 1987).

45. S. Riahi, M. Soussi, K. Bou Khalfa, K. Ben Ismail-Lattrache, D. A. V. Stow, S. Khomsi, and M. Bedir, "Stratigraphy, sedimentology and structure of the Numidian Flysch thrust belt in northern Tunisia," Afr. J. Earth Sci. 57, 109-126 (2009).

46. L. Rigo, S. Garde, H. El Euchi, K. Bandt, and J. Tiffert, "Mesozoic fractured reservoirs in a compressional structural model for North-Eastern Tunisia Atlasic zone," Tunis. Pet. Explor. Prod., Mem. 10, 233-355 (1996).

47. S. Shahram, M. Matteo, D. Frizon de Lamotte, and L. Jean, "Detachment folding in the Central and Eastern Zagros fold-belt (Iran): Salt mobility, multiple detachments and late basement control," J. Struct. Geol. 27, 1680-1696 (2005).

48. W. Wildi, "La chaîne tello-rifaine (Algérie-Maroc-Tunisie) : Structure, stratigraphie et évolution du Trias au Miocène," Rev. Geol. Dyn. Geogr. Phys. 24, 201-298 (1983). 